\title{
Chemical ozone loss in the Arctic winter 1991-1992
}

\author{
S. Tilmes ${ }^{1}$, R. Müller ${ }^{2}$, R. J. Salawitch ${ }^{3}$, U. Schmidt ${ }^{4}$, C. R. Webster ${ }^{3}$, H. Oelhaf ${ }^{5}$, C. C. Camy-Peyret ${ }^{6}$, and \\ J. M. Russell III ${ }^{7}$ \\ ${ }^{1}$ National Center for Atmospheric Research, Boulder, Colorado, USA \\ ${ }^{2}$ Institute for Stratospheric Research (ICG-1), Forschungszentrum Jülich, Germany \\ ${ }^{3}$ Jet Propulsion Laboratory, California Institute of Technology, California, USA \\ ${ }^{4}$ J.W. Goethe University Frankfurt, Germany \\ ${ }^{5}$ IMK-ASF, Forschungszentrum Karlsruhe, Karlsruhe, Germany \\ ${ }^{6}$ Universite Pierre et Marie Curie and CNRS, Ivry-sur-Seine, France \\ ${ }^{7}$ Hampton University, Virginia 23668, USA
}

Received: 20 April 2007 - Published in Atmos. Chem. Phys. Discuss.: 12 July 2007

Revised: 31 January 2008 - Accepted: 29 February 2008 - Published: 31 March 2008

\begin{abstract}
Chemical ozone loss in winter 1991-1992 is recalculated based on observations of the HALOE satellite instrument, Version 19, ER-2 aircraft measurements and balloon data. HALOE satellite observations are shown to be reliable in the lower stratosphere below $400 \mathrm{~K}$, at altitudes where the measurements are most likely disturbed by the enhanced sulfate aerosol loading, as a result of the Mt. Pinatubo eruption in June 1991. Significant chemical ozone loss (13$17 \mathrm{DU}$ ) is observed below $380 \mathrm{~K}$ from Kiruna balloon observations and HALOE satellite data between December 1991 and March 1992. For the two winters after the Mt. Pinatubo eruption, HALOE satellite observations show a stronger extent of chemical ozone loss towards lower altitudes compared to other Arctic winters between 1991 and 2003. In spite of already occurring deactivation of chlorine in March 1992, MIPAS-B and LPMA balloon observations indicate that chlorine was still activated at lower altitudes, consistent with observed chemical ozone loss occurring between February and March and April. Large chemical ozone loss of more than 70 DU in the Arctic winter 1991-1992 as calculated in earlier studies is corroborated here.
\end{abstract}

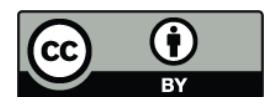

Correspondence to: S. Tilmes

(tilmes@ucar.edu)

\section{Introduction}

The Arctic winter 1991-1992 was a climatological moderately warm winter. For this winter, chemical processes in the polar vortex were strongly influenced by the enhanced burden of sulfate aerosols after the eruption of Mt. Pinatubo in June 1991, in particular at altitudes below $16 \mathrm{~km}(\approx 425 \mathrm{~K})$ (Browell et al., 1993). Strong chlorine activation and significant chemical ozone loss was observed (e.g., Waters et al., 1993; Toohey et al., 1993; Proffitt et al., 1993; Salawitch et al., 1993; Brandtjen et al., 1994). The amount of chemical ozone loss was quantified in several previous studies (e.g., Proffitt et al., 1993; Rex et al., 1998; Müller et al., 2001). These studies were based on different data sets: ER-2 aircraft measurements from the Airborne Arctic Stratospheric Expedition II (AASE-II) (Anderson et al., 1991; Toohey et al., 1993), data from the European Arctic Stratospheric Ozone Experiment (EASOE) (Pyle et al., 1994), namely observations from balloon-borne whole air samplers and ozone sondes. Further, ozone loss was derived using satellite observations from the Halogen Occultation Experiment (HALOE) (Russell et al., 1993) and from the microwave limb sounder (MLS) measurements (Tilmes et al., 2004; Manney et al., 2003), both aboard the UARS satellite.

These studies consistently found ozone loss of $\approx 25 \%$ in mid-winter (up to the end of January) and large ozone loss rates during January (Salawitch et al., 1993; von der Gathen et al., 1995). Further, model studies for January indicated largest chemical ozone loss in the outer part of the vortex due to a longer solar exposure (Lefèvre et al., 1994). Müller et al. (2001) and Tilmes et al. (2004) derived

Published by Copernicus Publications on behalf of the European Geosciences Union. 


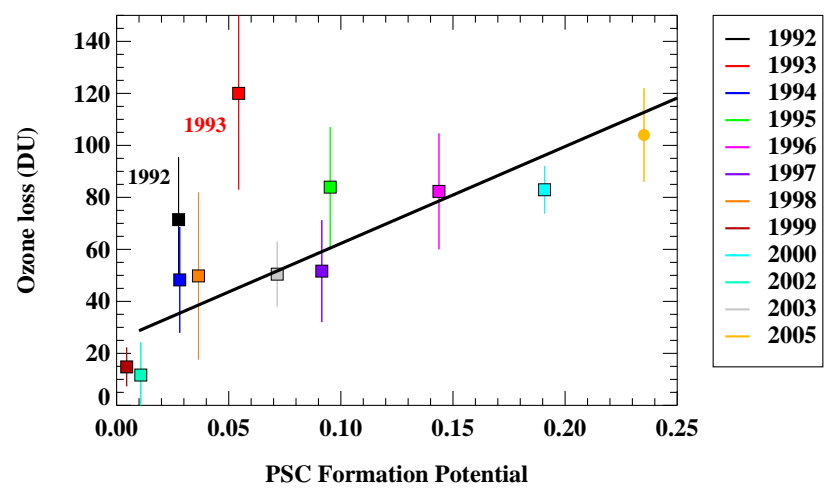

Fig. 1. Relation between the column ozone loss (DU) in March and the PSC formation potential (PFP) for the years 1992 to 2005 between $380-550 \mathrm{~K}$ using the tracer-tracer method (colored solid squares), taken from Tilmes et al. (2006) for the Arctic, only. Ozone loss values for March 1992 are taken from this work. The linear relation for the Arctic (calculated excluding winters 1992 and 1993 that are strongly impacted by the eruption of Mt. Pinatubo) is shown as a black line. Moreover, ozone loss values calculated from the $\mathrm{O}_{3}$ measurements onboard M55 Geophysica (solid circle) (von Hobe et al., 2006) are shown. Here, 1992 refers to the Arctic winter 19911992.

chemical ozone loss from HALOE satellite observations of 72 to 90 DU in February, March and April, using tracer-tracer correlations. Largest loss in column ozone was found below $450 \mathrm{~K}$. However, the burden of aerosol particles in this year was strongly enhanced due to the volcanic eruption of Mt. Pinatubo in June, for altitudes up to $25 \mathrm{~km}(\approx 700 \mathrm{~K})$ in mid-latitudes, and especially below $16 \mathrm{~km}(\approx 425 \mathrm{~K})$ in polar regions (Browell et al., 1993). Retrieved HALOE O 3 mixing ratios were strongly overestimated in situations of heavy aerosol loading before a correction had been applied (Hervig et al., 1995). After a correction of the data, the uncertainty of $\mathrm{O}_{3}$ mixing ratios was estimated to be $25 \%$ under normal conditions (Hervig et al., 1995). Brühl et al. (1996) performed a detailed evaluation of HALOE (Version 17) ozone profiles and reported differences to validation data of no more than $20 \%$ in the case of heavy aerosol loading in the lower stratosphere.

It is well established that enhanced stratospheric sulfate aerosol leads to greater halogen induced chemical ozone destruction (e.g., Cox et al., 1994; Tabazadeh et al., 2002; Rex et al., 2004; Tilmes et al., 2004; WMO, 2007). Model simulations by Tabazadeh et al. (2002) predicted a large increase of chemical ozone loss after a strong volcanic eruption, especially at lower altitudes (below $17 \mathrm{~km}$ ). For the Arctic winters 1991-1992 and 1992-1993, after the eruption of Mt. Pinatubo, Tilmes et al. (2006) reported strong chemical ozone loss based on an analysis of HALOE satellite observations. These values are outliers from the compact empirical relationship between chemical ozone loss and the PSC (polar stratospheric cloud) formation potential (PFP) ${ }^{1}$ for winters between 1991 and 2005, as shown in Fig. 1.

Winter 1991-1992 was characterized by a relatively small PFP value corresponding to a climatologically moderately warm winter. Based on this relationship, the influence of enhanced sulfate aerosols on chemical ozone loss is about $40 \mathrm{DU}$ for altitudes between $380-550 \mathrm{~K}$ potential temperature and about $20 \mathrm{DU}$ between $400-500 \mathrm{~K}$ potential temperature in winter 1991-1992 (Tilmes et al., 2006). However, up to now the question remains whether the enhanced chemical ozone loss derived in Tilmes et al. (2006) is the result of chemical processes, or whether observations are distorted by the enhanced sulfate aerosols and feign unreal chemical ozone loss. Rex et al. (2004) reported the impact of enhanced sulfate aerosol on chemical ozone loss to be smaller based on ozone sonde data than in Tilmes et al. (2006) (about 10 DU between 400-550 K) for this winter. For winter 1992-1993, Rex et al. (2006) do not find a significant impact of enhanced sulfate aerosol on ozone loss.

As described above, the presence of the sulfate aerosol in the stratosphere caused by the eruption of Mt. Pinatubo has severely affected the remote sensing measurements of the radiometer channels of the HALOE experiment (Hervig et al., 1995). Here, we will address the question whether the large chemical ozone loss values during spring 1992 based on HALOE observations (Tilmes et al., 2006) are an artifact caused by uncertain observations, or if this much ozone loss can result from chemical processes, which are not included in the PFP value used for the linear relationship in Fig. 1.

The goal of this paper is to derive the most reliable value of chemical ozone loss for the winter 1991-1992. For the first time for this winter, we combine all relevant available insitu observations, which are balloon-borne tracer measurements (Schmidt et al., 1994; Müller et al., 2001) and highaltitude aircraft ER-2 measurements (Proffitt et al., 1993) to validate the HALOE satellite observations. We will show that HALOE observations in winter 1991-1992 are reliable, especially at lower altitudes. This finding should be also conferrable to measurements in winter 1992-1993, a winter that also shows a strongly enhanced aerosol burden.

Tracer-tracer correlations are used to derive chemical ozone loss as described in Sect. 2. Using this technique transport processes within the polar vortex are accounted for (e.g., Tilmes et al., 2004). Compared to other methods, this has the advantage that a possible mis-calculation of transport processes from models for a winter shortly after a volcanic eruption (Robock, 2001) do not affect the calculation of chemical ozone loss. We consider various observations, as there are aircraft, balloon and satellite observations to describe the reliability of the data sets, as described in Sect. 3. The meteorology of the Arctic winter 1991-1992 is described in Sect. 4.

\footnotetext{
${ }^{1}$ PFP presents the fraction of the vortex, over an ozone loss season in Arctic or Antarctica, exposed to PSC temperatures (Tilmes et al., 2006).
} 
Depending on the location of the observations, either inside or outside the polar vortex, air masses indicate different characteristics. The location of measurements with respect to the polar vortex will be discussed in detail in Sect. 5. Based on this information, chemical ozone loss is derived as described in Sect. 6. Further, a comparison of ozone loss profiles for different Arctic winters will be discussed.

Polar chemical ozone loss is a result of chlorine activation in connection with sunlight in the polar vortex. Starting in late December 1991, strong chlorine activation and enhanced $\mathrm{ClO}$ were observed until late February in the Arctic lower stratosphere (Waters et al., 1993; Toohey et al., 1993). Enhanced OClO is reported for as late as 11 March (Brandtjen et al., 1994). In Sect. 7, we use balloon measurements in mid-March 1992 (von Clarmann et al., 1993; Oelhaf et al., 1994; Wetzel et al., 1995) to further scrutinize the vertical structure of chlorine activation in March 1992 in the polar vortex.

\section{Method}

In this study, the tracer-tracer correlation method is used to derive chemical ozone loss in the Arctic polar vortex. The relationship between ozone and a long-lived tracer will not change unless active chlorine (formed by heterogeneous chemistry) causes substantial ozone loss, because of sufficiently long life-times of the tracers in the lower stratosphere in winter. Further, if the polar vortex is isolated and mixing across the vortex edge can be neglected, changes from the relation between ozone and a long-lived tracer in the early winter (the early winter reference function) can be assumed to be a result of chlorine activation and subsequent chemical ozone loss (e.g. Proffitt et al., 1993; Tilmes et al., 2004).

The validity of the tracer-tracer correlations (TRAC) technique as a method to deduce chemical ozone loss has been debated in the literature (e.g., Michelsen et al., 1998; Plumb et al., 2000; Salawitch et al., 2002; Tilmes et al., 2004; Müller et al., 2005, and references therein). Plumb et al. (2000) state that "estimates of ozone depletion inferred from $\mathrm{O}_{3}$ :tracer relations are likely to be overestimates" due to the effect of mixing across the vortex edge. As summarized in the following, this concern is not valid under the conditions considered here. In the conceptual model used by Plumb et al. (2000) diffusivities for transport across the vortex edge are employed that are very likely too high by more than an order of magnitude (Müller et al., 2005). Moreover, the conceptual model is formulated in terms of artificial, chemically inert tracers $\chi_{1}$ and $\chi_{2}$. Salawitch et al. (2002) have demonstrated that the model results for $\chi_{1}$ and $\chi_{2}$ should not be applied to the interpretation of the $\mathrm{O}_{3} / \mathrm{N}_{2} \mathrm{O}$ relation in the Arctic vortex. In the model used by Plumb et al. (2000), the development of the $\chi_{1}-\chi_{2}$ relation is driven primarily by supply of air at the top of the vortex with near zero mixing ratios of both species. However, ozone mixing ratios at the top of the vortex are typically greater than those in the vortex after chemical ozone loss occurred. Even though air low in ozone exists in the mesosphere, photochemical model calculations indicate that $\mathrm{O}_{3}$ is quickly regenerated to mixing ratios of 3-4 ppm by normal gas phase photochemistry as these air parcels descend to lower than $\approx 40 \mathrm{~km}$ (Salawitch et al., 2002). Indeed ozone mixing ratios ranging between 3.6-5.6 ppm have been measured in the mesospheric air-masses that have intruded into the Arctic stratosphere in early 2003 (Müller et al., 2007).

To apply the technique carefully (Tilmes et al., 2004; Müller et al., 2005), the location of profiles has to be discussed with respect to the polar vortex edge to understand if they are influenced by air masses from outside the vortex. Profiles which are located within or outside the boundary region of the polar vortex show different characteristics. A detailed description of the technique and a discussion of the uncertainties due to mixing processes is given in Tilmes et al. (2004) and Müller et al. (2005). The polar vortex edge and the poleward edge of the vortex boundary region are calculated as defined by Nash et al. (1996), based on the PV gradient as a function of equivalent latitude. A more precise selection of vortex profiles is performed for aircraft observations with a large horizontal resolution, described in Sect. 5. The area poleward of the vortex boundary region is defined as the vortex core; the area of the vortex outside the vortex core is defined as the vortex boundary region (Tilmes et al., 2004).

\section{Observations}

In this study, we use satellite observations taken from the HALOE instrument (Russell et al., 1993), Version 19. HALOE measurements made during January, February, March and April 1992 were within the polar vortex core (vortex boundary region for January). HALOE $\mathrm{CH}_{4}$ and $\mathrm{HF}$ are suitable long-lived tracers to apply to the tracer-tracer correlation method as described in Tilmes et al. (2004). The satellite instrument uses gas filter channels to measure these long-lived tracers, different than ozone, which is observed using radiometer channels. The gas filter channels are only weakly affected by aerosol particles and, therefore, a correction of these species for aerosol interference was not necessary (Hervig et al., 1995). Based on a comprehensive validation study, Brühl et al. (1996) reported that ozone mixing ratios have an uncertainty of no more than $20 \%$ in the peak aerosol layer in the lower stratosphere (caused by the Mt. Pinatubo eruption) after a correction of the data (Hervig et al., 1995). Although Brühl et al. (1996) used an earlier HALOE version (Version 17) than the one used here (Version 19), the improvements made in the newer data version should not deteriorate the quality of the aerosol correction. Major modifications were made between Version 17 and 18 

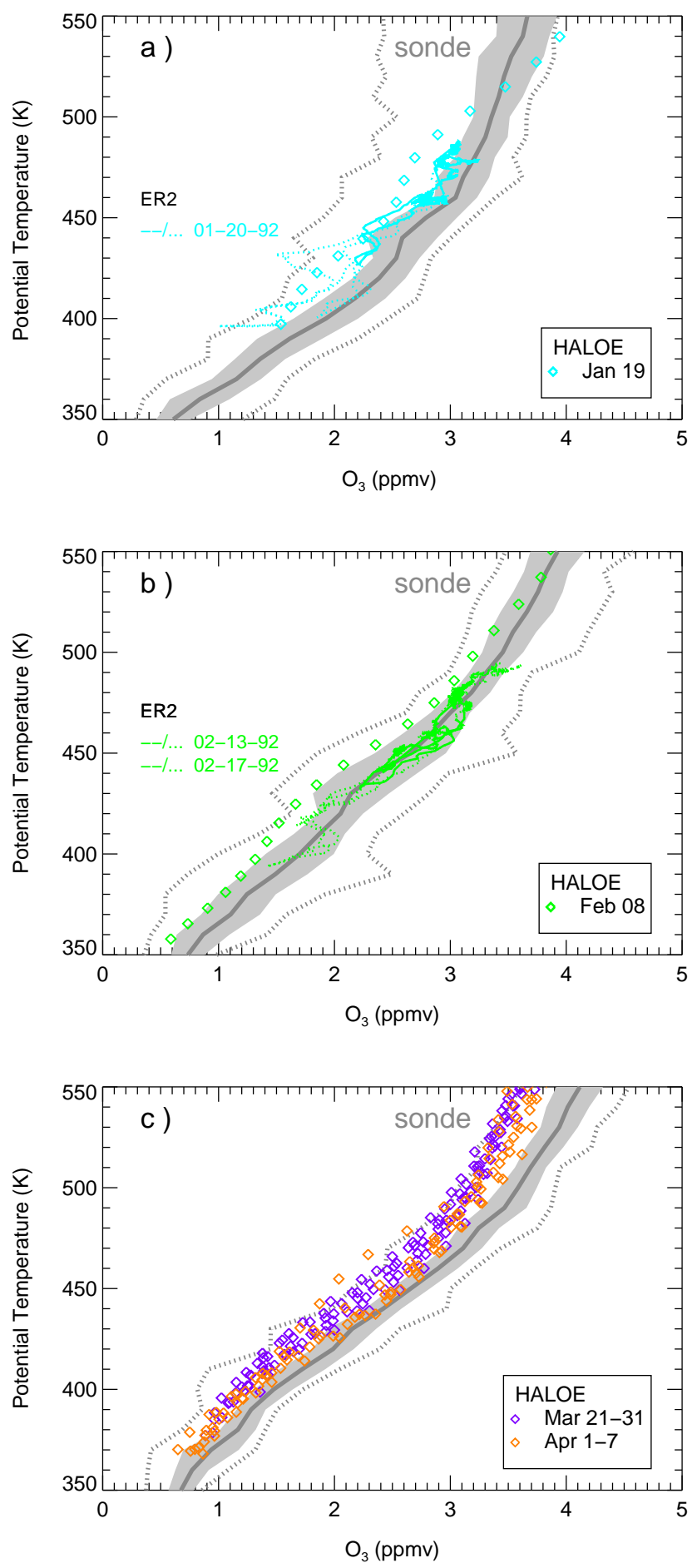

Fig. 2. Ozone mixing ratios are shown with respect to potential temperature taken by the HALOE satellite (diamonds) and ER-2 aircraft observations inside the vortex core (solid lines) and inside the entire vortex (dotted lines) in comparison to ozone sonde data inside the vortex core, for January (top), February (middle) and March 1992 (bottom). The averaged ozone sonde profile is shown as a grey solid line with a standard deviation shaded in grey and maximum and minimum mixing ratios as dotted lines. and the Version 19 data. Version 19 data have a better accuracy for the retrieved species at altitudes below $70 \mathrm{hPa}$.

To quantify the uncertainty of HALOE ozone data in the Arctic lower stratosphere in spring 1992, we compare HALOE ozone mixing ratios with a large number of ozone sonde observations taken within the polar vortex core and with ER-2 observations (described below). Fig. 2 shows the average ozone sonde profile and the standard deviation derived for January (panel a), February (panel b) and March (panel c) 1992. Extreme values are shown. Using an established criterion by Nash et al. (1996) to identify vortex profiles, ozone sonde data taken within the polar vortex show a rather homogeneous distribution with a standard deviation between 0.1 and $0.2 \mathrm{ppm}$ for January and March and up to 0.34 ppm in February (grey shaded area in Fig. 2)

For both January and February, only one HALOE profile is available in the vortex. In January, the profile is located close to the polar vortex edge. Ozone mixing ratios are slightly lower compared to the average ozone sonde profile for February for most of the considered altitude range. Especially between 400 and $450 \mathrm{~K}$ ozone mixing ratios are up to $0.4 \mathrm{ppm}$ lower (around $420 \mathrm{~K}$ ) than the average ozone sonde profile. Nevertheless, HALOE mixing ratios are still in the range of minimum observed ozone sonde data. Between 350 and $400 \mathrm{~K}$, a region where HALOE ozone profiles were most strongly influenced by high aerosol loading, profiles in February agree well with ozone sonde data and deviate by less than $0.2 \mathrm{ppm}$ from the mean ozone sonde profile. Additionally, ER2 observations agree well with ozone sonde data.

For March and the beginning of April, HALOE observations are in agreement with ozone sonde data within the range of observed ozone sonde profiles. As in February, HALOE ozone mixing ratios are slightly lower than the averaged ozone sonde profile, by about 0.2 and $0.3 \mathrm{ppm}$ between 380 and $500 \mathrm{~K}$, with less deviation towards lower latitudes. In summary, HALOE ozone measurements are within the range of the ozone sonde measurements in the polar vortex and show a deviation of less than $0.2 \mathrm{ppm}$ below $400 \mathrm{~K}$. This analysis corroborats our conclusions that HALOE ozone observations are reliable in the Arctic polar vortex and ozone loss can be derived from this data set. The influence of a possible uncertainty of $0.25 \mathrm{ppm}$ on derived chemical ozone loss is discussed below.

Besides ozone sonde observations, balloons were launched in Kiruna, Sweden, during the Arctic winter between December 1991 and March 1992 employing cryogenic (Schmidt et al., 1987) and whole air grab sampling techniques (Bauer et al., 1994) that measured long-lived tracers like $\mathrm{N}_{2} \mathrm{O}$ and $\mathrm{CH}_{4}$. Ozone observations were concurrently taken by standard electrochemical-concentration-cell sondes (Pyle et al., 1994). In addition, we use ER-2 aircraft observations of $\mathrm{N}_{2} \mathrm{O}$ and $\mathrm{CH}_{4}$ taken by the ALIAS instrument (Webster et al., 1994) and the ATLAS instrument (Loewenstein et al., 1993) and $\mathrm{O}_{3}$ from the dual beam photometer (Proffitt and McLaughlin, 1983). 

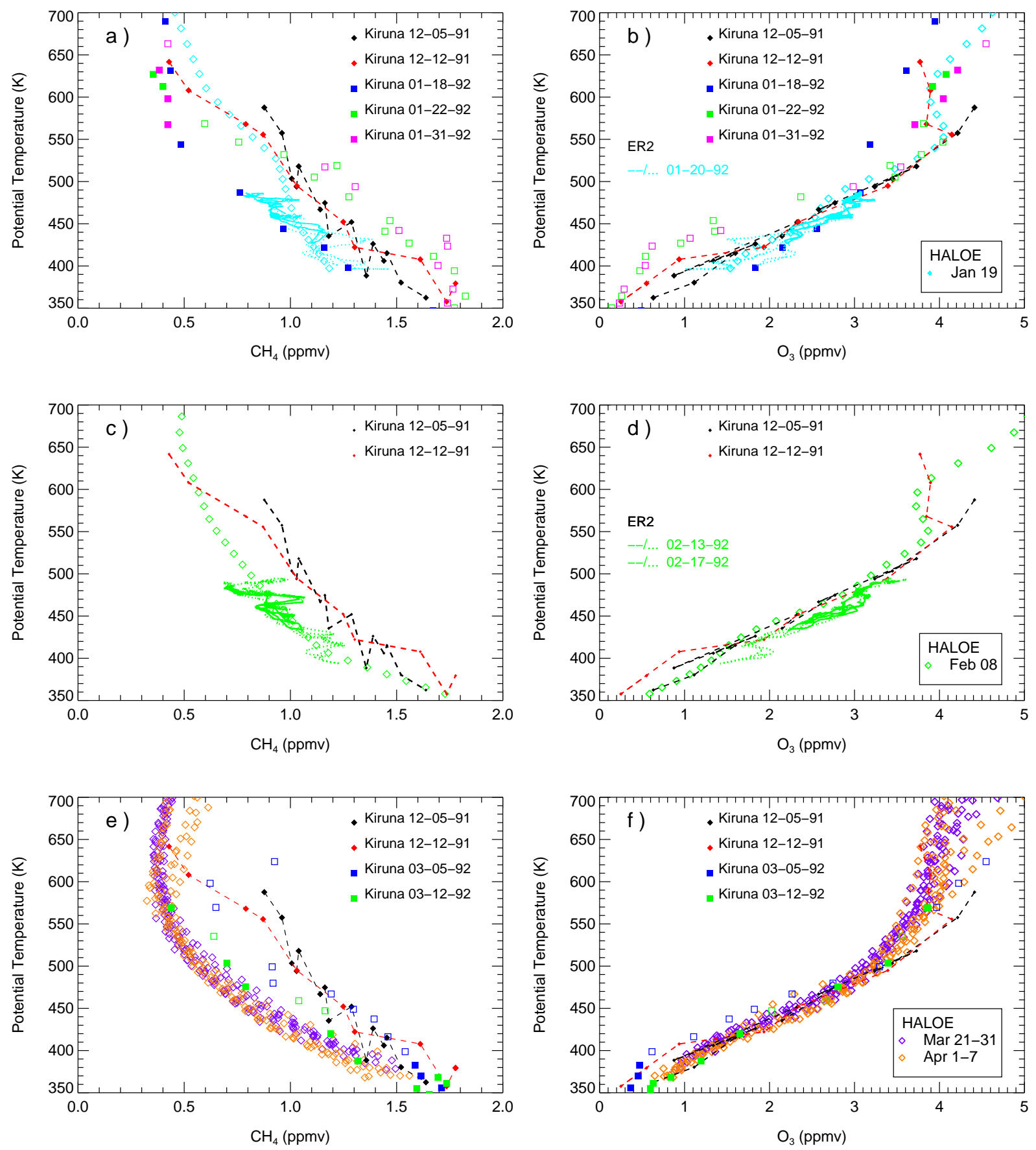

Fig. 3. $\mathrm{CH}_{4}$ (left column) and $\mathrm{O}_{3}$ (right column) mixing ratios with respect to potential temperature taken by the HALOE satellite, Kiruna balloons in the vortex core (filled symbols) and outside the vortex core (open symbols), and ER-2 aircraft observations within the vortex core (solid lines) and within the entire vortex (dotted lines), for different periods: January (top), February (middle) and March 1992 (bottom). Kiruna balloon observations during December (red and black symbols and dashed lines) are shown in each panel as early winter reference profiles.

During January and February, the ER-2 observed air masses well within the polar vortex core. In-situ balloon and ER-2 observations of ozone mixing ratios are not influenced by enhanced sulfate aerosols in the lower stratosphere and can be used as a comparison to HALOE satellite observa- tions (as shown in Fig. 2).

We compare $\mathrm{O}_{3}$ and $\mathrm{CH}_{4}$ profiles for the different measurements as well as the relationship between $\mathrm{O}_{3} / \mathrm{CH}_{4} . \mathrm{N}_{2} \mathrm{O}$ balloon and aircraft observations were converted to $\mathrm{CH}_{4}$ mixing ratios using a $\mathrm{CH}_{4} / \mathrm{N}_{2} \mathrm{O}$ tracer relation derived using 

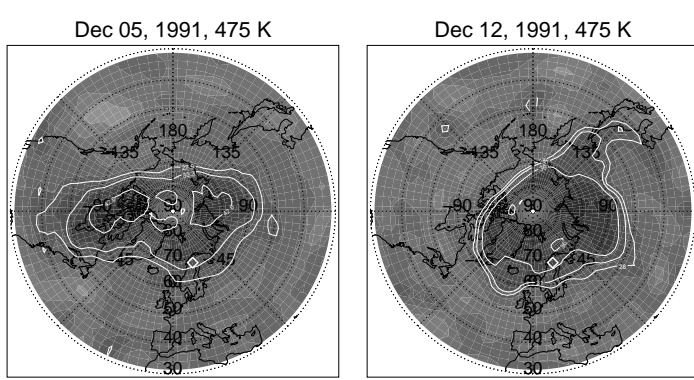

$10^{-6 *} \mathrm{~m}^{2} /\left(\mathrm{kg}^{*} \mathrm{~s}\right)$

Jan $18,1992,475 \mathrm{~K}$

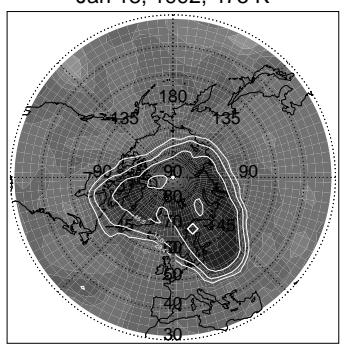

Jan $20,1992,475 \mathrm{~K}$

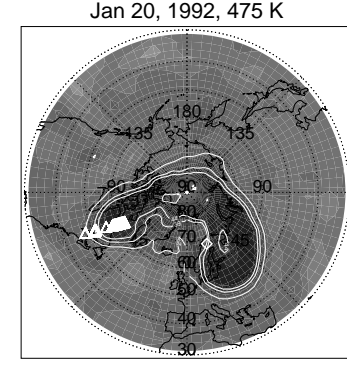

$10^{-6 *} \mathrm{~m}^{2} /\left(\mathrm{kg}^{*} \mathrm{~s}\right)$
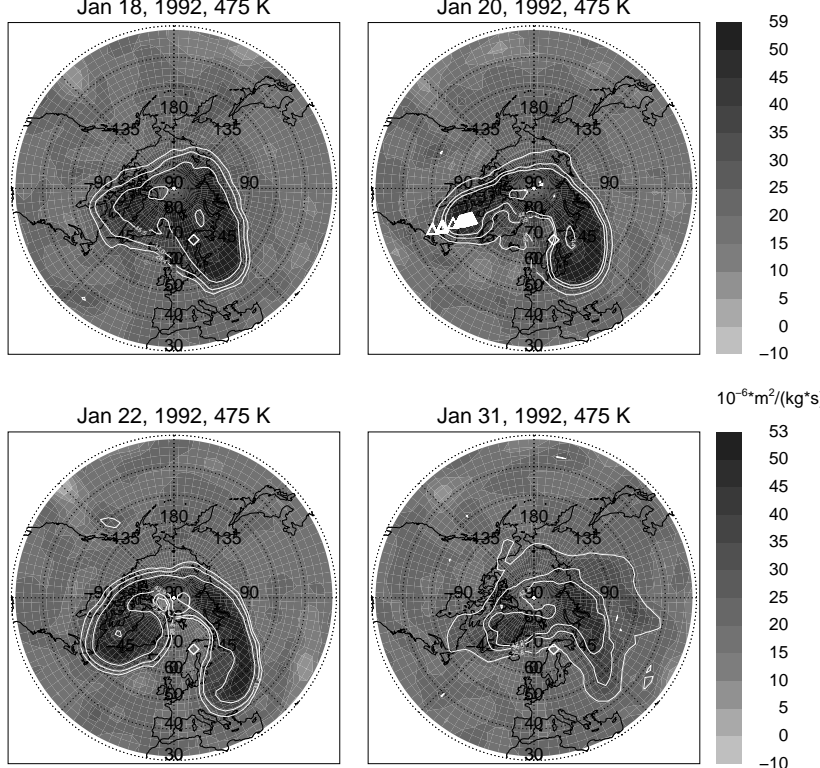

Fig. 4. Potential vorticity derived from MetO analysis on the $475 \mathrm{~K}$ potential temperature level valid for 5, 12 December 1991, and 18, 20, 22 and 31 January 1992, 12:00 UTC. White lines indicate the location of the polar vortex core, edge, and outer edge of the vortex as defined by Nash et al. (1996). The location of Kiruna is marked as a white diamond. For the same altitude the location of ER-2 aircraft measurements are presented as white triangles for 20 January, only (taken within $8 \mathrm{hr}$ at the day shown).

whole air sampler measurements, reported in Tilmes et al. (2006). The uncertainty of $\mathrm{CH}_{4}$ using the $\mathrm{CH}_{4} / \mathrm{N}_{2} \mathrm{O}$ tracer relation is $\sigma \approx 50 \mathrm{ppb}$ and will be included in the error estimate of chemical ozone loss derived below.

Additionally, two balloon-borne experiments were launched from Kiruna on 14 March 1992. MIPAS-B took measurements of several trace gases including $\mathrm{CH}_{4}$ and $\mathrm{ClONO}_{2}$ and LPMA measured $\mathrm{HCl}$ and $\mathrm{CH}_{4}$ (von Clarmann et al., 1993; Camy-Peyret, 1994; Oelhaf et al., 1994; Wetzel et al., 1995). MIPAS-B is a cryogenic Fourier Transform Spectrometer recording limb emission spectra and LPMA performs solar occultation infrared measurements. For these instruments broadband high spectral resolution spectroscopy was used. The aerosol contributions in the spectra can well be accounted for in the retrieval (e.g., Echle et al., 1998).
Earlier, $\mathrm{HCl} /$ tracer relations based on HALOE satellite observations were investigated by Tilmes et al. (2004) to estimate possible chlorine activation in the polar vortex.

\section{Meteorology of the Arctic vortex 1991-1992}

The polar vortex in winter 1991-1992 was cold between November and January and disturbed by several warming pulses (Naujokat et al., 1992). Temperatures were below $195 \mathrm{~K}$ (favorable conditions for chlorine activation by PSCs) only during January (Newman et al., 1993; Manney et al., 2003). Owing to the strongly enhanced sulfate aerosol densities in the lower stratosphere, the threshold temperature for chlorine activation increased significantly (Katja Drdla, pers. communication). Temperatures during the first part of February and the first half of March 1992 below $450 \mathrm{~K}$ are below this threshold and a potential of chlorine activation exists during this period. At the end of January, a major warming resulted in weaker, westerly zonal winds at $60^{\circ} \mathrm{N}$ for altitudes between 380 and $550 \mathrm{~K}$ (Naujokat et al., 1992). Transport of air into the vortex was reported by Grooß and Müller (2003). During February and March, the vortex was stable and broke down during April.

\section{Location of the observations}

The characteristic of the distribution of long-lived tracers in the polar region strongly depends on the location of observations. In the polar vortex, air masses descend most significantly at the beginning of the winter. Descent results in larger ozone and lower $\mathrm{CH}_{4}$ mixing ratios within the polar vortex than outside the vortex below about $600 \mathrm{~K}$, the region important for chemical ozone loss due to catalytic ozone destruction. Additionally, chemical ozone loss occurs during winter and spring within the Arctic vortex, if vortex temperatures reach values allowing chlorine activation, resulting in a decrease of ozone mixing ratios. In the vortex boundary region airmasses are influenced by air from outside the vortex as a result of isentropic mixing and show different distributions compared to airmasses within the polar vortex core. In order to discuss the reliability of satellite data, it is important to compare similar airmasses. We therefore define the location of various observations, based on whether they were observed within the vortex core, in the vortex boundary region or outside the vortex. In Fig. 3, we compare $\mathrm{CH}_{4}$ and $\mathrm{O}_{3}$ profiles of available observations in winter 1991-1992.

For HALOE satellite observations, we use the Nash et al. (1996) criterion to distinguish observations that are taken within the polar vortex core, the vortex boundary region and outside the vortex. In the following, only satellite profiles in the vortex and the vortex boundary region (denoted as "entire vortex") are considered. For ER-2 observations, only the part of the flight path within the entire polar vortex is considered. We use the potential vorticity $P V$, interpolated 
on the flight path to distinguish between measurements that have been taken inside and outside the polar vortex, as described in the following. The modified potential vorticity (Lait, 1994; Müller and Günther, 2003) $\Pi=P V \cdot\left(\theta_{0} / \theta\right)^{-\varepsilon}$ is employed, where $\theta$ is the potential temperature, $\theta_{0}=475 \mathrm{~K}$ is a reference potential temperature and the exponent $\varepsilon$ may be chosen to adjust the scaling to the prevailing temperature profile (Müller and Günther, 2003). Here, we use $\varepsilon=4.5$, based on the approximately isothermal temperature profiles measured by radiosonde and by the Microwave Temperature Profiler (MTP) aboard the ER-2 in January/February 1992. The potential vorticity at the edge of the vortex is calculated to be $P V=29$ PVU (potential vorticity units: $1 \mathrm{PVU}=10^{-6} \mathrm{~K}$ $\mathrm{m}^{2} /(\mathrm{kg} \mathrm{s})$ and at the edge of vortex core to be $P V=34 \mathrm{PVU}$ at $475 \mathrm{~K}$ during January and February 1992, using MetO data based on the Nash et al. (1996) criterion. Measurements with $\Pi$ larger $29 \mathrm{PVU}$ are assigned to the entire vortex (dotted lines) and measurements with $\Pi$ larger than 34 PVU are assigned to the vortex core (solid lines in Fig. 3).

Some of the available Kiruna balloon profiles represent the airmass composition at various locations relative to the vortex boundary as described by Bauer et al. (1994) and Schmidt et al. (1994). Observations taken inside the vortex core in January and March are shown as solid symbols, data outside the vortex core are shown as open symbols, in the following.

In Fig. 3, $\mathrm{CH}_{4}$ and $\mathrm{O}_{3}$ mixing ratios are shown for different periods and different observations. In each panel, a to $\mathrm{f}$, two Kiruna balloon data are shown as black and red dashed lines. The profile taken on 5 December 1991, black line, was located well inside the vortex for all altitudes. The profile taken on 12 December 1991, red line, was partly located inside the polar vortex, for altitudes above $475 \mathrm{~K}$, and partly outside but close to the vortex edge for altitudes at and below $475 \mathrm{~K}$ (compare Fig. 4, top row). Kiruna observations within the entire vortex are used as a reference for early winter conditions observed during December.

Figure 3, panels a and b, show ER-2, Kiruna and HALOE observations during January 1992 compared to the two Kiruna balloon observations in December. The Kiruna balloon observations on 18 January are located well inside the vortex, see also Fig. 4, middle, left panel.

Smaller $\mathrm{CH}_{4}$ mixing ratios compared to the reference profiles are a result of descent of the polar vortex between December and January. Profiles taken on 22 and 31 January 1992, over Kiruna, are located outside the polar vortex at altitudes below $500 \mathrm{~K}$ (see Fig. 4, bottom panels). Above $500 \mathrm{~K}$, the measurements show vortex characteristics with smaller $\mathrm{CH}_{4}$ mixing ratios compared to the reference profiles. The flight direction of the balloon, especially for the 31 of January, moved toward the vortex core. Additionally, ER2 aircraft observations were taken at locations between outside the vortex and deep inside the polar vortex on 20 January (Fig. 4, middle right panel, white triangles). Observations taken in the boundary area of the vortex show larger $\mathrm{CH}_{4}$ mixing ratios (dotted lines in Fig. 3, panel a). ER-2 $\mathrm{CH}_{4}$
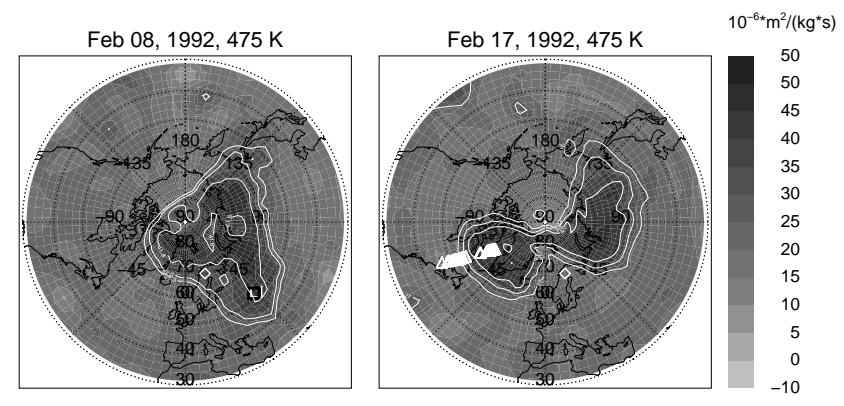

Fig. 5. Potential vorticity derived from MetO analysis on the $475 \mathrm{~K}$ potential temperature level valid for 8, 17 February 1992, 12:00 UTC. White lines indicate the location of the polar vortex core, edge, and outer edge of the vortex as defined by Nash et al. (1996). One available HALOE satellite profile inside the vortex core is represented as white squares and ER-2 aircraft measurements are presented as white triangle. The HALOE satellite profiles were repositioned to 12:00 UTC through trajectory calculations, black square.

mixing ratios and their deviation from the reference in the vortex core are in good agreement with the balloon observations over Kiruna on 18 January 1992. One HALOE satellite profile, taken on 19 January within the vortex boundary region (panel a and b, cyan diamonds), does not show lower $\mathrm{CH}_{4}$ mixing ratios and was influenced by air from outside the vortex.

The corresponding $\mathrm{O}_{3}$ profiles observed in January 1992 indicated minor deviations from the reference profile (see Fig. 3, panel b). ER-2 ozone mixing ratios and the balloon profile on January 18, observed within the vortex core, are slightly larger compared to the reference function due to the descent of vortex air masses. Kiruna balloon data on 22 and 31 January and HALOE observations in January show smaller ozone mixing ratios below $500 \mathrm{~K}$. These profiles were influenced by air masses with smaller ozone mixing ratios from outside the vortex, as also discussed by Müller et al. (2001). The smaller ozone mixing ratios on 18 January above $550 \mathrm{~K}$ are a result of the influence of out of vortex air.

In Fig. 3 panel $\mathrm{c}$ to $\mathrm{f}$, we compare $\mathrm{CH}_{4}$ and $\mathrm{O}_{3}$ mixing ratios of HALOE satellite observations taken within the vortex with Kiruna balloon observations (panel e and f) during March and ER-2 observations during February (panel $\mathrm{c}$ and d). All HALOE observations show smaller $\mathrm{CH}_{4}$ mixing ratios compared to the reference profile (panel c and e) and therefore indicate the descent of airmasses within the polar vortex between December and March/April. One HALOE profile was partly observed within the vortex core (below $500 \mathrm{~K}$ ) on February 8 and several profiles were observed at the end of March and the beginning of April in the polar vortex, as shown in Fig. 5.

ER-2 observations are only available within the polar vortex during January and February. All ER-2 observations during March were obtained outside the polar vortex (not 

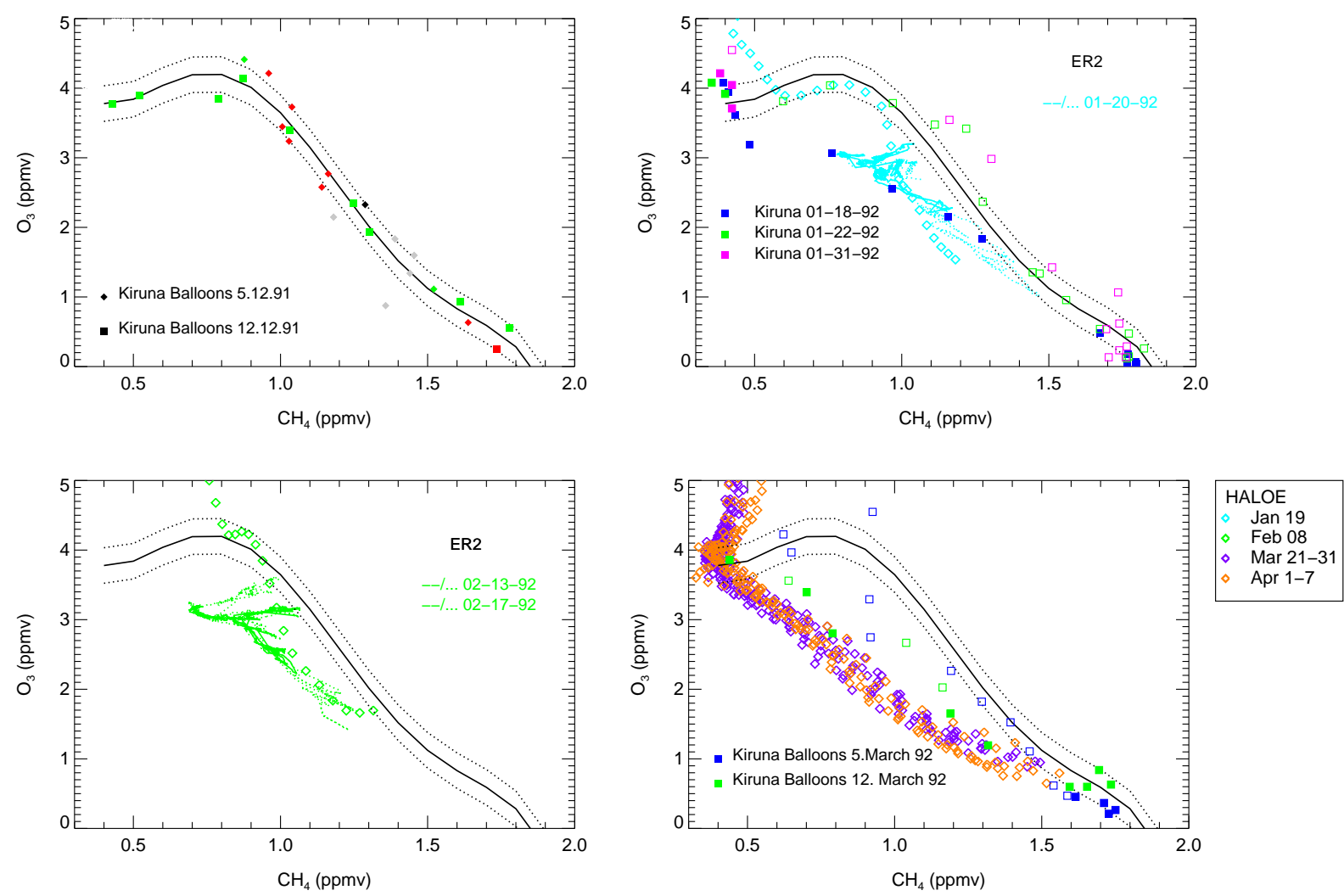

Fig. 6. $\mathrm{O}_{3} / \mathrm{CH}_{4}$ relations, the early winter reference function, shown as a black line in all four panels, was derived using Kiruna balloon data from 5 and 12 December 1991 (top left panel). Different colors indicate the position of the data, vortex core (green), entire vortex (red), vortex boundary region (black) and outside the vortex (grey). Top right panel: $\mathrm{O}_{3} / \mathrm{CH}_{4}$ relations during January 1992 using ER-2 aircraft measurements within the entire vortex (cyan dotted lines) and within the vortex core (cyan solid lines), Kiruna balloon data within the vortex core (filled colored squares) and outside the vortex core (open colored squares) and HALOE satellite observations (cyan diamonds) within the polar vortex. Bottom panel: $\mathrm{O}_{3} / \mathrm{CH}_{4}$ relations during February (right panel) and March / April (left) in 1992 using ER-2 available aircraft measurements within the vortex (green lines) and HALOE satellite observations (colored diamonds) within the polar vortex.

shown). As for January, observations during February were taken at locations in the outer vortex and the vortex core. Observations show smallest $\mathrm{CH}_{4}$ mixing ratios and largest $\mathrm{O}_{3}$ mixing ratios at particular theta levels if they were taken deep inside the vortex core. $\mathrm{CH}_{4}$ profiles taken within the vortex core are in good agreement with HALOE observations. ER-2 ozone mixing ratios (Fig. 3 panel d) are slightly larger $(0.2-0.3 \mathrm{ppm})$ in February compared to HALOE observations for the same potential temperature level. This can be a result of a sampling of air masses that experienced less ozone depletion in the observed part of the vortex compared to HALOE ozone observations in February. Slightly inhomogeneous ozone depletion in the vortex is also reflected by a larger standard deviation of ozone profiles in February, as discussed above (see Fig. 2, panel b).

The Kiruna balloon profile observed on 12 March 1992 (Fig. 3, panel e, green squares) indicates a similar characteristic as the HALOE observations between March and April between 350 and $420 \mathrm{~K}$, at $475 \mathrm{~K}$ and above $550 \mathrm{~K}$. During its flight, the balloon moved towards the edge of the vortex for the other altitudes as described by Bauer et al. (1994) and Schmidt et al. (1994). Ozone mixing ratios of the balloon profile in 12 March 1992 and satellite observations in March and April 1992 are in agreement, see panel f. The balloon profile taken over Kiruna on 5 March was located in the vortex boundary region (Fig. 3, panel e, blue squares) and does not show significant deviations from the reference profiles (black and red lines in Fig. 3) below $500 \mathrm{~K}$. As described above, a deviation from the reference $\mathrm{CH}_{4}$ profile indicates the measured air mass has descended diabatically. The agreement of the balloon profile on 5 March and the reference profiles, below $500 \mathrm{~K}$, indicates that measured air masses were located outside the vortex where descent did not occur. Therefore, this profile is characterized by air from outside the vortex below $500 \mathrm{~K}$ and should not be compared to observations inside the polar vortex.

In summary, $\mathrm{CH}_{4}$ and $\mathrm{O}_{3}$ mixing ratios of the considered observations agree well if observed within the polar vortex core. Profiles observed outside the polar vortex core show larger $\mathrm{CH}_{4}$ mixing ratios and smaller $\mathrm{O}_{3}$ mixing ratios as a 
result of the influence of outer vortex air for altitudes below $600 \mathrm{~K}$. It is shown that $\mathrm{HALOE} \mathrm{O}_{3}$ and $\mathrm{CH}_{4}$ observations are reliable between 350 and $700 \mathrm{~K}$. Observations are in good agreement with ER-2 observations below $550 \mathrm{~K}$ potential temperature and with Kiruna balloon observations taken within the polar vortex core in January and March.

\section{Chemical ozone loss}

\subsection{Tracer-tracer correlations}

To estimate chemical ozone loss, we derived an $\mathrm{O}_{3} / \mathrm{CH}_{4}$ early winter reference function based on balloon observations taken on 5 and 12 December 1991, that are located in the entire polar vortex (Fig. 6, top panel). On 12 December, balloon data were measured well inside the polar vortex core (green symbols). On 5 December most of the observations were located within the entire polar vortex (red symbols). Profiles around $400 \mathrm{~K}$ were located outside the vortex boundary region (grey squares) and are not included in the calculation of the early winter reference function (Fig. 6, top panel).

This reference function is constructed as a simple unweighted least square polynominal fit to the data points of the order of 5, which is slightly improved compared to Tilmes et al. (2004) and Müller et al. (2001).

$$
\begin{array}{r}
\mathrm{O}_{3}=-12.1793 \cdot\left(\mathrm{CH}_{4}\right)^{5}+69.3824 \cdot\left(\mathrm{CH}_{4}\right)^{4} \\
-145.932 \cdot\left(\mathrm{CH}_{4}\right)^{3}+136.509 \cdot\left(\mathrm{CH}_{4}\right)^{2} \\
-56.2627 \cdot \mathrm{CH}_{4}+12.1302
\end{array}
$$

The standard deviation of the derived reference function is $\sigma=0.255 \mathrm{ppm}$. The value used to calculate the uncertainty of the loss in column ozone is $0.39 \mathrm{ppm}$. It was derived by combining (as root mean square) the uncertainty of the reference function $\sigma=0.255 \mathrm{ppm}$, the uncertainty of the $\mathrm{CH}_{4}$ to $\mathrm{N}_{2} \mathrm{O}$ conversion (of $50 \mathrm{ppb} \mathrm{CH}_{4}$ ), which results in 0.14 ppm uncertainty of ozone loss, plus the uncertainty of HALOE ozone observations in comparison to ozone sonde data in spring of $0.25 \mathrm{ppm}$.

During January, ER-2 aircraft observations indicate significant deviation from the early winter reference function, (Fig. 6, top, right panel). Kiruna balloon observations taken within the vortex core on 18 January, as discussed above, agree well with ER-2 observations. Kiruna profiles that are influenced by outer vortex air scatter above the reference function. HALOE observations in January show less deviation from the reference function than ER-2 observations due to the location outside the polar vortex core.

During February, ER-2 observations indicate a larger deviation from the early winter reference function compared to January. Therefore, further chemical ozone loss has occurred. Later in March and April, ER-2 aircraft observations are not considered, because they were taken far outside of the polar vortex (not shown). HALOE satellite ob-
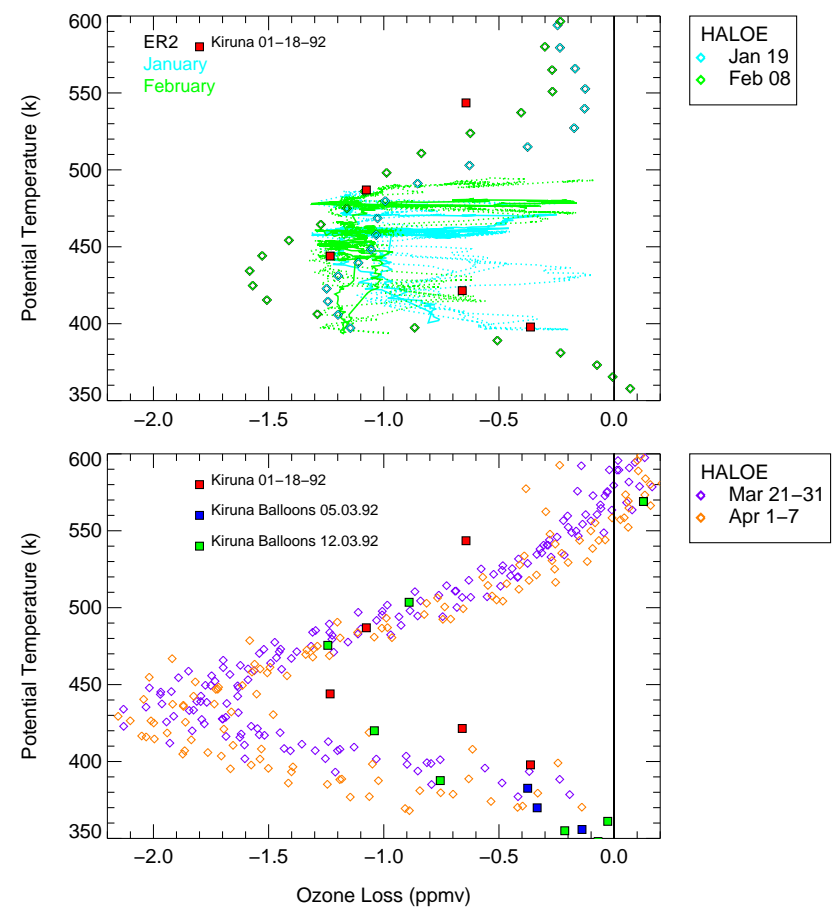

Fig. 7. Ozone loss profiles derived from $\mathrm{O}_{3} / \mathrm{CH}_{4}$ tracer relations between mid-December 1991 and January/February 1992 (top panel) and mid-December and March/April (bottom panel). HALOE and balloon data observed in the vortex core are shown, as well as ER2 aircraft data in the entire vortex (dotted lines) and in the vortex core (solid lines).

servations during February are in agreement with ER-2 data (Fig. 6 green diamonds and lines). Further, Kiruna balloon data on 12 March show similar deviations from the early winter reference function as HALOE observations obtained in March and April, within the polar vortex core between 350 and $420 \mathrm{~K}$, at $475 \mathrm{~K}$, and above $550 \mathrm{~K}$ (as discussed above).

\subsection{Local chemical ozone loss}

Accumulated ozone loss profiles between December 1991 and observations in January to April 1992 are shown in Fig. 7. During January, local chemical ozone loss up to $1.3 \mathrm{ppm}$ is reached between $400 \mathrm{~K}$ and $480 \mathrm{~K}$ based on ER2 data and Kiruna balloon data (red squares). In the vortex boundary region, one HALOE profile shows less ozone loss (up to $0.8 \mathrm{ppm}$ ) in January. The observed chemical ozone loss during January is in agreement with the large ozone loss values observed in mid-winter (e.g. von der Gathen et al., 1995). Further, $\mathrm{HCl} / \mathrm{CH}_{4}$ profiles observed by HALOE in the vortex boundary region indicate significant chlorine activation (Tilmes et al., 2004) and strongly enhanced ClO mixing ratios were observed (Waters et al., 1993; Toohey et al., 1993). In January and February a significant increase of local ozone loss is obvious only for one HALOE profile (19 January and 8 February, respectively) measured within the polar 

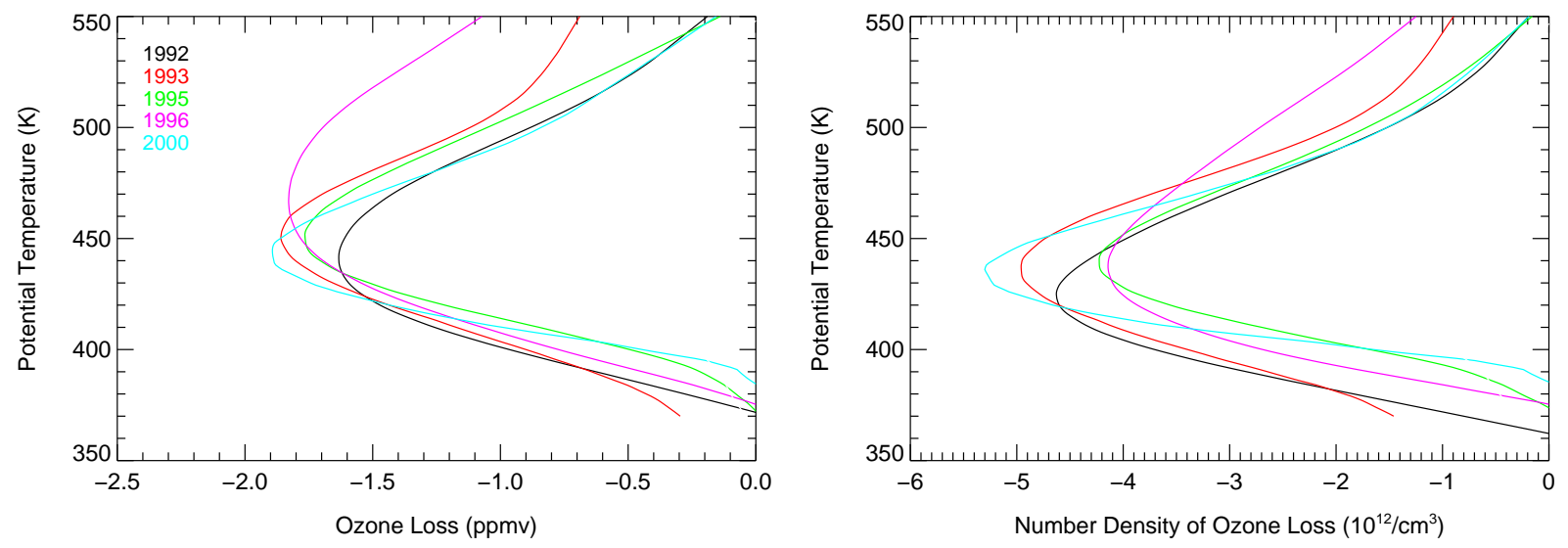

Fig. 8. Averaged ozone loss profiles for March/April for winter 1991-1992, 1992-1993 and cold Arctic winters 1994-1995, 1995-1996 and 1999-2000.

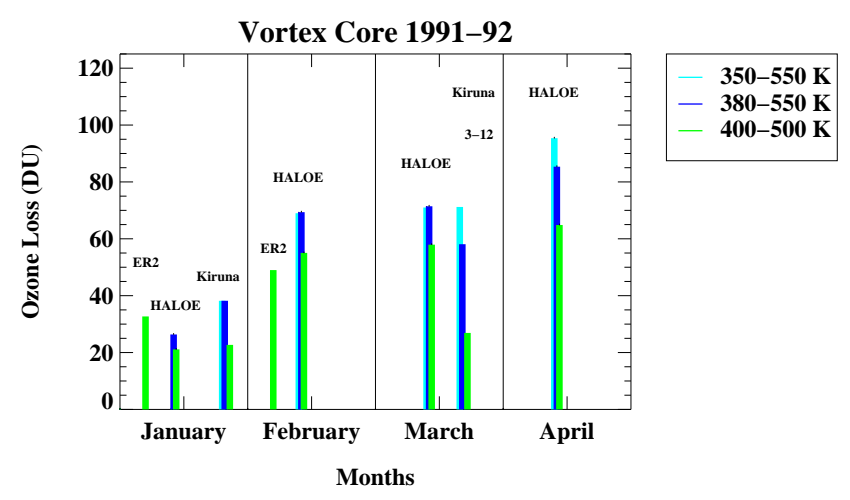

Fig. 9. Accumulated chemical loss in column ozone for different altitude intervals and different months in winter 1991-1992, derived using ER-2 aircraft measurements, HALOE satellite observations, and Kiruna balloon measurements within the vortex core, for different partial columns (see legend). Measurements are placed on the chart based on the month during which they were obtained; the placement within the month is not meant to indicate the precise timing of the observations.

vortex core. Later in March and April, HALOE observations show local ozone loss values between 1.6 and $2.1 \mathrm{ppm}$ between 420 and $460 \mathrm{~K}$. Additional ozone loss is possible during March and April due to possible chlorine activation during March, as described in Sect. 7, and the increase in solar illumination on the polar vortex in spring. Local ozone loss derived using the Kiruna balloon profile on 12 March 1992, (green squares) is in agreement with HALOE observations below $400 \mathrm{~K}$ and above $470 \mathrm{~K}$, at altitudes where the balloon was located within the polar vortex core, as discussed above. Especially at altitudes below $380 \mathrm{~K}$, Kiruna balloon observations show large local ozone loss. All observations shown in Fig. 7 are located inside the polar vortex edge.

The impact of enhanced sulfate aerosols in the lower stratosphere after the Mt. Pinatubo eruption is obvious in comparing averaged ozone loss profiles for March/April of different winters between 1991 and 2003 (see Fig. 8). The winter 1991-1992 and 1992-1993 show enhanced ozone loss at altitudes below $400 \mathrm{~K}$, black and red line, respectively. Further, the maximum ozone loss in winter 1991-1992 is located about $10 \mathrm{~K}$ below the maximum of the winter 19921993 and 1999-2000.

\subsection{Chemical loss in column ozone}

Chemical ozone loss in winter 1991-1992 is summarized in Fig. 9. Derived ozone loss values have an uncertainty of $\pm 32-38 \mathrm{DU}$ for altitudes between 350 and $550 \mathrm{~K}, \pm 24-$ $27 \mathrm{DU}$ for altitudes between 380 and $550 \mathrm{~K}$, and $\pm 15-16 \mathrm{DU}$ for altitudes between 400 and $500 \mathrm{~K}$ potential temperature. This uncertainty is estimated from the combination of the uncertainty of the early winter reference function (see Fig. 6, black dotted lines), the uncertainty of the $\mathrm{N}_{2} \mathrm{O}$ to $\mathrm{CH}_{4}$ conversion of balloon observations in the early winter, and an uncertainty of HALOE ozone observations in comparison to ozone sonde data in spring, as described above.

The standard deviation of the column ozone loss distribution (using the large amount of HALOE profiles in the vortex core) is $24 \mathrm{DU}$ in March and 13 DU in April, between 380 and $550 \mathrm{~K}$, and $19 \mathrm{DU}$ in March and $7 \mathrm{DU}$ in April, between 400 and $500 \mathrm{~K}$ potential temperature.

Between 400-500 K, chemical ozone loss increases from 33 DU in January (observed by ER-2 within the entire vortex) towards $65 \mathrm{DU}$ in April (observed by HALOE), as shown in Fig. 9, green columns. Between 380 and $550 \mathrm{~K}$, ozone loss reached 71 DU in March and 85 DU in April (blue columns). Balloon data in March show smaller ozone loss values in 380 and $550 \mathrm{~K}$, because of missing data between 420 and $470 \mathrm{~K}$ in the vortex core. Between $350-380 \mathrm{~K}$, as can be seen in the difference between the cyan and blue columns in Fig. 9, balloon data and HALOE observations indicate 


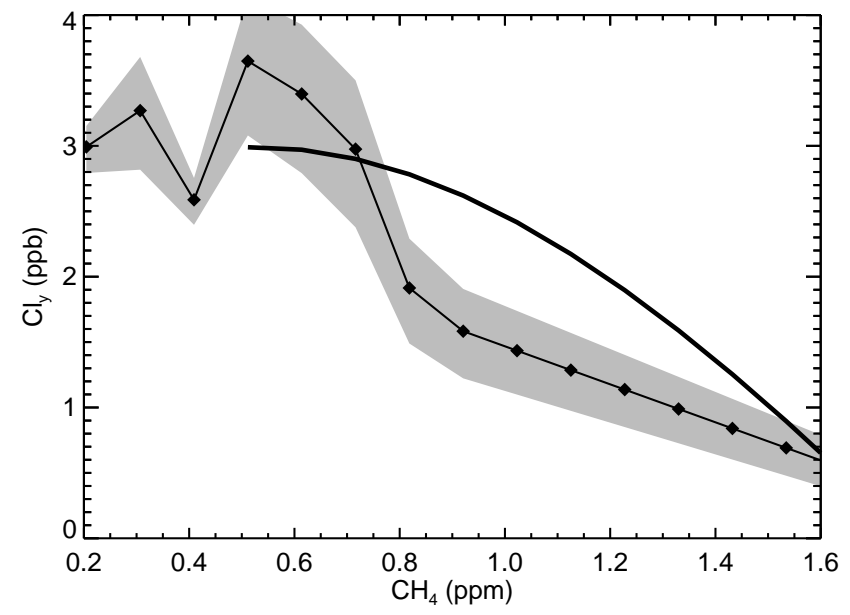

Fig. 10. The sum of $\mathrm{ClONO}_{2}$ (measured by MIPAS-B on 14/15 March 1992) and $\mathrm{HCl}$ (measured by LPMA on 14 March 1992) against methane mixing ratios, solid diamonds. The grey scale indicates the combined uncertainty range of $\mathrm{ClONO}_{2}$ and $\mathrm{HCl}$. Also shown is the $\mathrm{Cl}_{\mathrm{y}}^{\star} / \mathrm{CH}_{4}$ relation from Grooß et al. (2002) (solid black line) where $\mathrm{Cl}_{\mathrm{y}}^{\star}$ has been reduced by $12 \%$, to account for the lower chlorine loading in 1992 than in 2000 (WMO, 2007).

significant chemical ozone loss (13-17 DU) between December and March.

\section{Chlorine activation deduced from MIPAS-B and LPMA measurements}

Chemical ozone loss during February and March in the lower polar stratosphere is only possible if chlorine is still activated. Information about the two major chlorine reservoir species, $\mathrm{ClONO}_{2}$ and $\mathrm{HCl}$, is available from the balloon-borne measurements MIPAS-B and LPMA on 14 March 1992. By that time, chlorine deactivation in the Arctic vortex had proceeded and the majority of the active chlorine, $\mathrm{ClO}_{\mathrm{x}}\left(\mathrm{ClO}+2 \times \mathrm{Cl}_{2} \mathrm{O}_{2}\right)$, had been converted to $\mathrm{ClONO}_{2}$ (e.g., Toohey et al., 1993; Müller et al., 1994).

Here, we estimate the extent of chlorine activation still present in mid-March 1992. The abundance of inorganic chlorine $\mathrm{Cl}_{\mathrm{y}}$ can be estimated by the observed sum of $\mathrm{HCl}$ and $\mathrm{ClONO}_{2}$ from the balloon-borne measurements. Grooß et al. (2002) reported a $\mathrm{Cl}_{\mathrm{y}}^{\star} / \mathrm{CH}_{4}$ relation for deactivated conditions in $2000 . \mathrm{Cl}_{\mathrm{y}}^{\star}$ has been reduced by $12 \%$ to account for the lower chlorine loading in 1992 than in 2000 (WMO, 2007). The increase in methane (2\%) from 1992 to 2000 (Simpson et al., 2002) has only a minor effect but is also taken into account. The maximum $\mathrm{Cl}_{\mathrm{y}}^{\star}$ of about $3 \mathrm{ppb}$ at the lowest $\mathrm{CH}_{4}$ mixing ratios is in very good agreement with $\mathrm{Cl}_{\mathrm{y}}$ deduced independently from whole air sampler measurements for winter 1991/1992 (Schmidt et al., 1994). The comparison of the $\mathrm{Cl}_{\mathrm{y}}^{\star} / \mathrm{CH}_{4}$ relationship with the observed re-

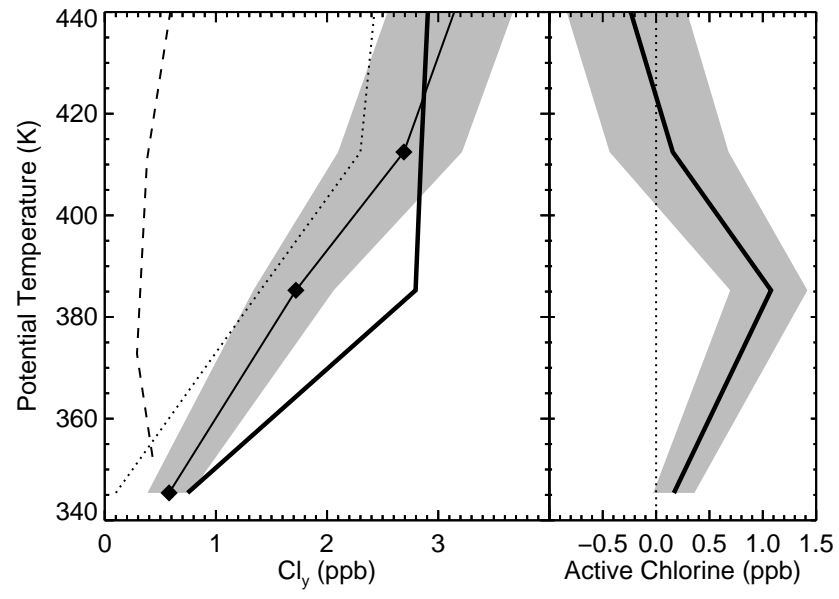

Fig. 11. Similar as in Fig. 10, but here the sum of $\mathrm{ClONO}_{2}$ and $\mathrm{HCl}$ mixing ratios (solid diamonds) is shown against potential temperature. The grey scale indicates the combined uncertainty range of $\mathrm{ClONO}_{2}$ and $\mathrm{HCl}$. Solid black line shows the adjusted $\mathrm{Cl}_{\mathrm{y}}^{\star}$ reference from Grooß et al. (2002), using the MIPAS-B methane measurements. Also shown are $\mathrm{ClONO}_{2}$ mixing ratios (from MIPAS$\mathrm{B}$, dotted line) and $\mathrm{HCl}$ (from LPMA, dashed line).

lation between $\left(\mathrm{HCl}+\mathrm{ClONO}_{2}\right) / \mathrm{CH}_{4}$ is shown in Fig. 10 . For methane mixing ratios greater than $\approx 0.8 \mathrm{ppm}$, the sum of $\mathrm{ClONO}_{2}$ and $\mathrm{HCl}$ is much lower than the estimated $\mathrm{Cl}_{\mathrm{y}}$. This indicates that chlorine is not yet completely deactivated in mid-March 1992.

In Fig. 11, left panel, the sum of the measured $\mathrm{ClONO}_{2}$ and $\mathrm{HCl}$ mixing ratios is compared against the estimated inorganic chlorine $\mathrm{Cl}_{\mathrm{y}}^{\star}$ on a potential temperature scale. Between about 345 and $400 \mathrm{~K}, \mathrm{Cl}_{\mathrm{y}}^{\star}$ exceeds the sum of $\mathrm{ClONO}_{2}$ and $\mathrm{HCl}$, showing that at those altitudes chlorine was still activated. The vertical profiles of $\mathrm{HCl}$ and $\mathrm{ClONO}_{2}$ on 14 March 1992 (dashed and dotted lines, respectively in Fig. 11) confirms that the deactivation that has occurred up to this date is dominated by the formation of $\mathrm{ClONO}_{2}$ (e.g., Toohey et al., 1993; Müller et al., 1994). HALOE $\mathrm{HCl} / \mathrm{CH}_{4}$ relations support this finding (Tilmes et al., 2004). Figure 11, right panel, shows the vertical profile of active chlorine on 14 March found as the difference between the estimated $\mathrm{Cl}_{\mathrm{y}}^{\star}$ and the observed sum of $\mathrm{ClONO}_{2}$ and $\mathrm{HCl}$ on 14 March 1992. Maximum active chlorine of $\approx 1 \mathrm{ppb}$ occurred around $380 \mathrm{~K}$.

Box model calculations (e.g., Canty et al., 2005) indicate that, for $1 \mathrm{ppb}$ of $\mathrm{ClO}_{\mathrm{x}}$ present at $65^{\circ} \mathrm{N}, 380 \mathrm{~K}$ on 20 March, calculated chemical loss rates are about $40 \mathrm{ppb}$ per day, which equals a loss of $4 \%$ per day when 1 ppm of ozone is present [Tim Canty, private communication, 2007]. The presence of activated $\mathrm{ClO}_{\mathrm{x}}$ in middle to late March in combination with the long period of sunlight leads to rapid ozone loss. This likely explains why ozone losses observed by HALOE in early April exceed those in March, particularly below $400 \mathrm{~K}$ (region of elevated $\mathrm{ClO}_{\mathrm{x}}$ ). 


\section{Discussion}

The comparison of different observations in the winter 19911992 results in a consistent picture of chemical ozone loss derived using tracer-tracer correlations. HALOE ozone observation were shown to agree well with observed ozone sonde observations in the Arctic polar vortex between January and March. The deviation between a monthly averaged ozone sonde profile and HALOE ozone is on average $0.3 \mathrm{ppm}$ at altitudes above $400 \mathrm{~K}$ potential temperature. Below $400 \mathrm{~K}$, an altitude which was very likely influenced by high aerosol loading after the eruption of Mt. Pinatubo, these data do not deviate by more than $0.2 \mathrm{ppm}$.

The detailed discussion about the location of profiles in Sect. 5 was performed to distinguish between profiles observed within the vortex core and the vortex boundary region. Profiles located within the polar vortex core show largest chemical ozone loss values, as observed by ER-2 during January and February and by HALOE between February and April. Kiruna balloon observations confirm larger local ozone loss values for observations taken within the polar vortex core.

During March, Kiruna balloon measurements and HALOE observations indicate chemical ozone loss of 13-17 DU below $380 \mathrm{~K}$. By mid-March 1992, chlorine deactivation had substantially proceeded, dominated by the formation of $\mathrm{ClONO}_{2}$. Nevertheless, balloon-borne measurements (Fig. 11) demonstrate that chlorine was still activated in the altitude range between 345 and $400 \mathrm{~K}$ potential temperature, with a maximum active chlorine of $\approx 1 \mathrm{ppb}$ occurring at $\approx 380 \mathrm{~K}$. These findings are in agreement with very low $\mathrm{HCl}$ mixing ratios observed by HALOE in the polar vortex between January and February below $450 \mathrm{~K}$ (Tilmes et al., 2004). Assuming active chlorine of $\approx 1 \mathrm{ppb}$, box model simulations show rapid ozone destruction of about $4 \%$ per day in March, which explains the additionally derived ozone loss between March and April 1992 based on HALOE observation.

The comparison of averaged ozone loss profiles of Arctic winters between 1991-1992 and 2002-2003, derived using HALOE observations, shows significantly larger ozone loss values at altitudes below $400 \mathrm{~K}$ for the years shortly after the Mt. Pinatubo eruption. Between 400 and $500 \mathrm{~K}$, chemical ozone loss values of $65 \pm 16 \mathrm{DU}$ are in agreement with values derived by Rex et al. (2004). Therefore, the influence of enhanced sulfate aerosols in altitudes between $400-550 \mathrm{~K}$ described by Rex et al. (2004) is in agreement with the results found here.

The comparison between ER-2, balloon and HALOE observations show a good agreement around and below $400 \mathrm{~K}$. This is the altitude where the uncertainty of HALOE was presumed to be largest due to aerosol interference. Further, column ozone loss between $400-500 \mathrm{~K}$ is in agreement for ER-2 and HALOE observations. Therefore, we conclude the influence of large aerosol loadings on HALOE measurements is small and ozone loss values calculated between February and April are reliable with and uncertainty of $15-16 \mathrm{DU}$ of the total loss. Chemical ozone loss in winter 1991-1992 is significantly larger than in comparable moderately warm winters, due presumably to enhanced chlorine activation caused by the highly enhanced volcanic aerosol loading.

\section{Conclusions}

In the moderately warm winter 1991-1992 significant chemical ozone loss was found as a result of the enhanced burden of sulfate aerosols in the lower stratosphere after the Mt. Pinatubo eruption in June 1991. The comparison of different observations corroborates results derived earlier from HALOE satellite observations, especially for altitudes below $400 \mathrm{~K}$. Between 400 and $500 \mathrm{~K}, 50-55 \pm 16$ DU of chemical ozone loss was estimated between December and February based on ER-2 and HALOE observations and up to $65 \pm 16$ DU between December and April based on HALOE observations. Between 380 and $550 \mathrm{~K}$ potential temperature, $71 \pm 26 \mathrm{DU}$ of chemical ozone loss in March and $86 \pm 27 \mathrm{DU}$ during April is deduced from HALOE observations. For altitudes below $380 \mathrm{~K}$, ozone loss of $13 \mathrm{DU}$ in March was derived based on Kiruna balloon observations and 17 DU in April based on HALOE observations, in agreement with activated chlorine of $\approx 1 \mathrm{ppb}$ occurring at $\approx 380 \mathrm{~K}$ in midMarch 1992.

Acknowledgements. We gratefully acknowledge all members of the HALOE team at NASA Langley for their work in producing a high-quality data set. We further acknowledge Tim Canty, for performing box model simulations. Thanks are also due to the UK Meteorological Office and the European Centre for Medium-range Weather Forecasts for providing meteorological analyses. In particular, we acknowledge M. Proffitt for providing high quality ozone profiles and $\mathrm{M}$. Loewenstein for providing $\mathrm{N}_{2} \mathrm{O}$ profiles taken during the AASE II mission. The University Corporation for Atmospheric Research (UCAR) supported this work.

Edited by: A. Richter

\section{References}

Anderson, J. G., Toohey, D. W., and Brune, W. H.: Free Radicals Within the Antarctic Vortex: The Role of CFCs in Antarctic Ozone Loss, Science, 251, 39-46, 1991.

Bauer, R., Engel, A., Franken, H., Klein, E., Kulessa, G., Schiller, C., and Schmidt, U.: Monitoring the vertical structure of the Arctic polar vortex over northern Scandinavia during EASOE: Regular $\mathrm{N}_{2} \mathrm{O}$ profile observations, Geophys. Res. Lett., 21(13), 1211-1214, 1994.

Brandtjen, R., Klüpfel, T., Perner, D., and Knudsen, B.: Airborne measurements during the European Arctic Stratospheric Ozone Experiment: Observations of OClO, Geophys. Res. Lett., 21(13), 1363-1366, 1994. 
Browell, E. V., Butler, C. F., Fenn, M. A., Grant, W. B., Ismail, S., Schoeberl, M., Toon, O. B., Loewenstein, M., and Podolske, J. R.: Ozone and Aerosol Changes During the 1991-1992 Airborne Arctic Stratospheric Expedition, Science, 261, 1155-1158, 1993.

Brühl, C., Drayson, S. R., Russell, J. M. I., Crutzen, P. J., McInerney, J. M., Purcell, P. N., Claude, H., Gernandt, H., McGee, T. J., McDermid, I. S., and Gunson, M. R.: Halogen Occultation Experiment ozone channel validation, J. Geophys. Res., 101(D6), 10,217-10,240, 1996.

Camy-Peyret, $\mathrm{C}$.: $\mathrm{HCl}$ and $\mathrm{CH}_{4}$ profiles obtained from balloonborne FTIR during EASOE, Ann. Geophys., 12, 1994.

Canty, T., Rivir, E. D., Salawitch, R. J., Berthet, G., Renard, J.-B., Pfeilsticker, K., Dorf, M., Butz, A., Stimpf, H. B. R., Wilmouth, D., Richard, E., Fahey, D., Popp, P., Schoeberl, M., Lait, L., and Bui, T.: Nighttime OClO in the winter Arctic vortex, J. Geophys. Res., 110, DO1301, doi:10.1029/2004JD005035, 2005.

Cox, R., MacKenzie, A., Müller, R., Peter, T., and Crutzen, P.: Activation of stratospheric chlorine by reactions in liquid sulfuricacid, Geophys. Res. Lett., 21(13), 1439-1442, 1994.

Echle, G., von Clarmann, T., and Oelhaf, H.: Optical and microphysical parameters of the Mt. Pinatubo aerosol determined from MIPAS-B mid-IR limb emission spectra, J. Geophys. Res., 103, 19193-19211, 1998.

Grooß, J.-U. and Müller, R.: The impact of mid-latitude intrusions into the polar vortex on ozone loss estimates, Atmos. Chem. Phys., 3, 395-402, 2003, http://www.atmos-chem-phys.net/3/395/2003/.

Grooß, J.-U., Günther, G., Konopka, P., Müller, R., McKenna, D. S., Stroh, F., Vogel, B., Engel, A., Müller, M., Hoppel, K., Bevilacqua, R., Richard, E., Webster, C. R., Elkins, J. W., Hurst, D. F., Romashkin, P. A., and Baumgardner, D. G.: Simulation of ozone depletion in spring 2000 with the Chemical Lagrangian Model of the Stratosphere (CLaMS), J. Geophys. Res., 107, 8295, doi:10.1029/2001JD000456, 2002.

Hervig, M. E., Russell, III, J. M., Larry, L., Daniels, J., Drayson, R. S., and Park, J. H.: Aerosol effects and corrections in the Halogen Occultation Experiment, J. Geophys. Res., 100, 1067-1079, 1995.

Lait, L. R.: An alternative form for potential vorticity, J. Atmos. Sci., 51, 1754-1759, 1994.

Lefèvre, F., Brasseur, G. P., Folkins, I., Smith, A. K., and Simon, P.: Chemistry of the 1991-92 stratospheric winter: Threedimensional model simulations, J. Geophys. Res., 99, 81838195, 1994.

Loewenstein, M., Podolske, J. R., Fahey, D. W., Woodbridge, E. L., Tin, P., Weaver, A., Newman, P. A., Strahan, S. W., Kawa, S. R., Schoeberl, M. R., and Lait, L. R.: New observations of the $\mathrm{NOy} / \mathrm{N}_{2} \mathrm{O}$ correlation in the lower stratosphere, Geophys. Res. Lett., 20(22), 2531-2534, doi:10.1029/93GL03004, 1993.

Manney, G. L., Froidevaux, L., Santee, M. L., Livesey, N. J., Sabutis, J. L., and Waters, J. W.: Variability of ozone loss during Arctic winter (1991 to 2000) estimated from UARS Microwave Limb Sounder measurements, J. Geophys. Res., 108, doi:10.1029/2002JD002634, 2003.

Michelsen, H. A., Manney, G. L., Gunson, M. R., and Zander, R.: Correlations of stratospheric abundances of $\mathrm{NO}_{\mathrm{y}}, \mathrm{O}_{3}, \mathrm{~N}_{2} \mathrm{O}$, and $\mathrm{CH}_{4}$ derived from ATMOS measurements, J. Geophys. Res., 103, 28 347-28 359, 1998.
Müller, R. and Günther, G.: A generalized form of Lait's modified potential vorticity, J. Atmos. Sci., 60, 2229-2237, 2003.

Müller, R., Crutzen, P. J., Oelhaf, H., Adrian, G. P., v. Clarmann, T., Wegner, A., Schmidt, U., and Lary, D.: Chlorine chemistry and the potential for ozone depletion in the Arctic stratosphere in the winter of 1991/92, Geophys. Res. Lett., 21, 1427-1430, 1994.

Müller, R., Schmidt, U., Engel, A., McKenna, D. S., and Proffitt, M. H.: The $\mathrm{O}_{3} / \mathrm{N}_{2} \mathrm{O}$ relationship from balloon-borne observations as a measure of Arctic ozone loss in 1991-1992, Q. J. R. Meteorol. Soc., 127, 1389-1412, 2001.

Müller, R., Tilmes, S., Konopka, P., Grooß, J.-U., and Jost, H.-J.: Impact of mixing and chemical change on ozone-tracer relations in the polar vortex, Atmos. Chem. Phys., 5, 3139-3151, 2005, http://www.atmos-chem-phys.net/5/3139/2005/.

Müller, R., Tilmes, S., Grooß, J.-U., Engel, A., Oelhalf, H. and Wetzel, G.: Impact of mesopheric intrusions on ozone-tracer relations in the stratospheric polar vortex, J. Geophys. Res., 112, D23307, doi:10.1029/2006JD008315, 2007.

Nash, E. R., Newman, P. A., Rosenfield, J. E., and Schoeberl, M. R. An objective determination of the polar vortex using Ertel's potential vorticity, J. Geophys. Res., 101, 9471-9478, 1996.

Naujokat, B., Petzold, K., Labitzke, K., Lenschow, R., Rajewski, B., Wiesner, M., and Wohlfart, R.: The stratospheric winter 1991/92, the winter of the European Arctic Stratospheric Ozone Experiment, Beilage zur Berliner Wetterkarte, Freie Universität Berlin, 1992.

Newman, P. A., Lait, L. R., Schoeberl, M. R., Nash, E. R., Kelly, K., Fahey, D. W., Nagatani, R., Toohey, D., Avallone, L., and Anderson, J.: Stratospheric meteorological conditions in the Arctic polar vortex, 1991-1992, Science, 261, 1143-1156, 1993.

Oelhaf, H., v. Clarmann, T., Fischer, H., Friedl-Vallon, F., Fritzsche, C., Linden, A., Piesch, C., Seefeldner, M., and Völker, W.: Stratospheric $\mathrm{ClONO}_{2}$ and $\mathrm{HNO}_{3}$ profiles inside the Arctic vortex from MIPAS-B limb emission spectra obtained during EASOE, Geophys. Res. Lett., 21, 1263-1266, doi:10.1029/93GL01303, 1994.

Plumb, R. A., Waugh, D. W., and Chipperfield, M. P.: The effect of mixing on tracer relationships in the polar vortices, J. Geophys. Res., 105, 10 047-10 062, 2000.

Proffitt, M. H. and McLaughlin, R. J.: Fast-response dual-beam UV absorption ozone photometer suitable for use on stratospheric balloons, Rev. Sci. Instr., 54, 1719-1728, 1983.

Proffitt, M. H., Aikin, K., Margitan, J. J., Loewenstein, M., Podolske, J. R., Weaver, A., Chan, K. R., Fast, H., and Elkins, J. W.: Ozone loss inside the northern polar vortex during the 1991-1992 winter, Science, 261, 1150-1154, 1993.

Pyle, J. A., Harris, N. R., Farman, J. C., Arnold, F., Braathen, G., Cox, R. A., Faucaon, P., Jones, R. L., Megie, G., O’Neill, A., Platt, U., Pommereau, J.-P., Schmidt, U., and Stordal, F. An overview of the EASOE campaign, Geophys. Res. Lett., 21, 1191-1194, doi:10.1029/93GL03231, 1994.

Rex, M., von der Gathen, P., Harris, N. R. P., Lucic, D., Knudsen, B. M., Braathen, G. O., Reid, S. J., De Backer, H., Claude, H., Fabian, R., Fast, H., Gil, M., Kyrö, E., Mikkelsen, I. S., Rummukainen, M., Smit, H. G., Stähelin, J., Varotsos, C., and Zaitcev, I.: In situ Measurements of stratospheric ozone depletion rates in the Arctic winter 1991/92: A Lagrangian approach, J. Geophys. Res., 103, 5843-5853, 1998.

Rex, M., Salawitch, R. J., von der Gathen, P., Harris, 
N. R., Chipperfield, M. P., and Naujokat, B.: Arctic ozone loss and climate change, Geophys. Res. Lett., 31, L04116, doi:10.1029/2003GL018844, 2004.

Rex, M., Salawitch, R., Deckelmann, H., von der Gathen, P., Harris, N., Chipperfield, M., Naujokat, B., Reimer, E., Allaart, M., Andersen, S., Bevilacqua, R., Braathen, G., Claude, H., Davies, J., Backer, H. D., Dier, H., Dorokov, V., Fast, H., Gerding, M., Godin-Beekmann, S., Hoppel, K., Johnson, B., Kyrö, E., Litynska, Z., Moore, D., Nakane, H., Parrondo, M., Risley, A., Jr., Skrivankova, P., Stübi, R., Viatte, P., Yushkov, V., and Zerefos, C.: Arctic winter 2005: Implications for stratospheric ozone loss and climate change, Geophys. Res. Lett., 33, L23808, doi:10.1029/2006GL026731, 2006.

Robock, A.: Volcanic eruptions and climate, Rev. Geophys., 38, 191-219, 2001.

Russell, J. M., Gordley, L. L., Park, J. H., Drayson, S. R., Tuck, A. F., Harries, J. E., Cicerone, R. J., Crutzen, P. J., and Frederick, J. E.: The Halogen Occultation Experiment, J. Geophys. Res., 98, 10777-10 797, 1993.

Salawitch, R. J., Wofsy, S. C., Gottlieb, E. W., Lait, L. R., Newman, P. A., Schoeberl, M. R., Loewenstein, M., Podolske, J. R., Strahan, S. E., Proffitt, M. H., Webster, C. R., May, R. D., Fahey, D. W., Baumgardner, D., Dye, J., Wilson, J. C., Kelly, K. K., Elkins, J. W., Chan, K. R., and Anderson, J. G.: Chemical loss of ozone in the Arctic polar vortex in the winter of 1991-1992, Science, 261, 1146-1154, 1993.

Salawitch, R. J., Margitan, J., Sen, B., Toon, G. C., Osterman, G. B., Rex, M., Elkins, J. W., Ray, E. A., Moore, F. L., Hurst, D. F., Romashkin, P. A., Bevilacqua, R. M., Hoppel, K., Richard, E. C., and Bui, T. P.: Chemical loss of ozone during the Arctic winter of 1999-2000: an analysis based on balloon-borne observations, J. Geophys. Res., 107(D20), 8269, doi:10.1029/2001JD000620, 2002.

Schmidt, U., Kulessa, G., Klein, E., Röth, E.-P., Fabian, P., and Borchers, R.: Intercomparison of balloon-borne cryogenic whole air samplers during the MAP/GLOBUS 1983 campaign, Planet Space Sci, 35, 647-656, 1987.

Schmidt, U., Bauer, R., Engel, A., Borchers, R., and Lee, J.: The variation of available chlorine $\mathrm{Cly}_{\mathrm{y}}$ in the Arctic polar vortex during EASOE, Geophys. Res. Lett., 21, 1215-1218, doi:10.1029/93GL01053, 1994.

Simpson, I. J., Blake, D. R., and Rowland, F. S.: Implications of the recent fluctuations in the growth rate of troposheric methane, Geophys. Res. Lett., 29(10), doi:10.1029/2001GL014521, 2002.

Tabazadeh, A., Drdla, K., Schoeberl, M. R., Hamill, P., and Toon, O. B.: Arctic "ozone hole" in a cold volcanic stratosphere, Proc. Natl. Acad. Sci., 99(5), 2609-2612, 2002.
Tilmes, S., Müller, R., Grooß, J.-U., and Russell, J. M.: Ozone loss and chlorine activation in the Arctic winters 1991-2003 derived with the tracer-tracer correlations, Atmos. Chem. Phys., 4(8), 2181-2213, 2004.

Tilmes, S., Müller, R., Engel, A., Rex, M., and Russell III, J. M.: Chemical ozone loss in the Arctic and Antarctic stratosphere between 1992 and 2005, Geophys. Res. Lett., 33, LK20812, doi:10.1029/2006GL026925, 2006.

Toohey, D. W., Avallone, L. M., Lait, L. R., Newman, P. A., Schoeberl, M. R., Fahey, D. W., Woodbrige, E. L., and Anderson, J. G.: The seasonal evolution of reactive chlorine in the northern hemisphere stratosphere, Science, 261, 1134-1136, 1993.

von Clarmann, T., Fischer, H., Friedl-Vallon, F., Linden, A., Oelhaf, H., Piesch, C., and Seefeldner, M.: Retrieval of Stratospheric $\mathrm{O}_{3}$, $\mathrm{HNO}_{3}$ and $\mathrm{ClONO}_{2}$ Profiles From 1992 MIPAS-B Limb Emission Spectra: Method, Results, and Error Analysis, J. Geophys. Res., 98, 20 495-20 506, 1993.

von der Gathen, P., Rex, M., Harris, N. R. P., Lucic, D., Knudsen, B. M., Braathen, G. O., De Backer, H., Fabian, R., Fast, H., Gil, M., Kyrö, E., Mikkelsen, I. S., Rummukainen, M., Stähelin, J., and Varotsos, C.: Observational evidence for chemical ozone depletion over the Arctic in winter 1991-92, Nature, 375, 131134, doi:10.1023/A:1010607521870, 1995.

von Hobe, M., Ulanovsky, A., Volk, C. M., Grooß, J.-U., Tilmes, S., Konopka, P., Günther, G., Werner, A., Spelten, N., Shur, G., Yushkov, V., Ravegnani, F., Schiller, C., Müller, R., and Stroh, F.: Severe ozone depletion in the cold Arctic winter 2004-05, Geophys. Res. Lett., 33, L17815, doi:10.1029/2006GL026945, 2006.

Waters, J. W., Froidevaux, L., Read, W. G., Manney, G. L., Elson, L. S., Flower, D. A., Jarnot, R. F., and Harwood, R. S.: Stratospheric $\mathrm{ClO}$ and ozone from the Microwave Limb Sounder on the Upper Atmosphere Research Satellite, Nature, 362, 597-602, 1993.

Webster, C. R., May, R. D., Trimble, C. A., Chave, R. G., and Kendall, J.: Aircraft laser infrared absorption spectrometer (ALIAS) for in situ atmospheric measurements of $\mathrm{HCl}, \mathrm{N}_{2} \mathrm{O}$, $\mathrm{CH}_{4}, \mathrm{NO}_{2}$, and $\mathrm{HNO}_{3}$, Appl. Opt., 33, 454-472, 1994.

Wetzel, G., von Clarmann, T., Oelhaf, H., and Fischer, H.: Vertical profiles of $\mathrm{N}_{2} \mathrm{O}_{5}$ along with $\mathrm{CH}_{4}, \mathrm{~N}_{2} \mathrm{O}$, and $\mathrm{H}_{2} \mathrm{O}$ in the late Arctic winter retrieved from MIPAS-B infrared limb emission measuerements, J. Geophys. Res., 100(D11), doi:10.1029/95JD02344, 1995.

WMO: Scientific assessment of ozone depletion: 2006, Global Ozone Research and Monitoring Project-Report No. 50, Geneva, Switzerland, 2007. 